\title{
Page Layout and Braiding in Hergé's Seven Crystal Balls
}

\section{Hergé'nin 7 Kristal Küre'sinde Sayfa Düzeni ve Örme}

\author{
Rafael CARPINTERO ${ }^{10}$
}

1Prof. Dr., Istanbul University, Faculty of Letters, Department of Spanish Language and Literature, Istanbul, Turkey

\section{ORCID: R.C. 0000-0003-2790-5160}

\section{Corresponding author:} Rafael CARPINTERO,

Istanbul University, Faculty of Letters, Department of Spanish Language and Literature, Istanbul, Turkey

E-mail: ortega@istanbul.edu.tr

Submitted: 13.05.2021

Revision Requested: 29.05.2021 Last Revision Received: 29.05.2021 Accepted: 15.07.2021

Citation: Carpintero, R. Page layout and braiding in Hergé's Seven Crystal Balls. Litera, 31(2), 565-586.

https://doi.org/10.26650/LITERA2021-895987

\begin{abstract}
In the last years of the $20^{\text {th }}$ century, the Belgian scholar Thierry Groensteen developed a new way of analyzing comics in his book Système de la bande dessinée. The starting point is the notion of "iconic solidarity", by which separate but interrelated images form a significant unity. The relations that rule this iconic solidarity are called the "arthrology", governed by three fundamental operations: (a) Page layout as a result of gridding, or the distribution of the physical space; (b) Breakdown, or the division of the narrative content in panels; and (c) Braiding, or the interrelation of panels from a distance and not by narrative principles. All these operations create a delicate network in comics and any manipulation can alter it with negative results. A clear example can be found in Hergé's The Seven Crystal Balls. It had a very eventful publication process: first as daily strips, then as album pages, and last as double pages à l'italienne, occupying the whole width of the two pages. The pages prepared for the album suffered notable alterations in the braiding of the panels with the change of page layout from single page to double page. In this paper we will analyze the paradigmatic and syntagmatic consequences of changes in the conception of the page.
\end{abstract}

Keywords: Groensteen, braiding, page layout, system of comics, Hergé

öz

20. yüzyılın son yıllarında Belçikalı bilim adamı Thierry Groensteen Système de la bande dessinée başlıklı kitabında çizgi romanları çözümlemenin yeni bir yolunu geliştirmiştir. Çıkış noktası, ayrı ancak birbiriyle ilişkili imgeleri anlamlı bir birlik olarak ele alan"ikonik dayanışma" kavramıdır. Bu ikonik dayanışmayı yöneten, "artroloji" olarak adlandırılan ilişkiler üç temel işlem tarafından yönetilir: (a) Izgara oluşturmanın yani fiziksel uzamın dağılımının bir sonucu olarak sayfa düzeni; (b) Bölme yani anlatı içeriğinin panellere ayrılması; ve (c) Örme yani panellerin birbiriyle uzaktan ve anlatıma dayalı olmayan ilişkisi. Tüm bu işlemler çizgi romanlarda hassas bir ağ oluşturur ve herhangi bir değişiklik olumsuz sonuçlara yol açabilir. Apaçık bir örnek Hergé'nin The Seven Crystal Balls'unda bulunabilir. Çok olaylı bir yayın süreci olmuştur: önce günlük şeritler halinde, sonrasında albüm sayfaları biçiminde ve son olarak da iki sayfanın tüm genişliğini kaplayan çift à l'italienne (İtalyan usulü) sayfalar şeklinde. Tek sayfadan çift sayfaya geçilmesi ile, albüm için hazırlanan sayfalarda, panellerin örülme işleminde önemli değişiklikleri gerekli hale gelmiştir. Bu makalede, sayfa düzeninde yapılan değişiklikleri inceleyip değişikliklerin ortaya çıkardığı dizisel ve dizimsel sonuçlarını okurlara göstermeyi çalışacağız.

Anahtar Kelimeler: Groensteen, örme, sayfa düzeni, çizgi roman sistemi, Hergé 


\section{Introduction: Trends on comics studies}

The last forty years have witnessed an increase in the acceptance of comic studies in universities. The first ones were the semiotic studies of authors such as Umberto Eco -and, in Spain, Román Gubern - in the sixties and seventies, as well as other books and studies about, particularly, the graphic side of comics. In the eighties and nineties, two seminal works that changed the understanding of comics were published, both by comics authors themselves. The first one was Will Eisner's Comic and Sequential Art (1985). Eisner, who was a pioneer in the use of the term "graphic novel" to give his book Contract with God a respectable adult look, thinks that the essence of comics lies in their nature as a succession of images (panels) that narrates a story, opening the door to narratological research of comics as a medium distinctly different from literature (novels) and cinema. The second book that gave comics an air of "respectable art", was Understanding Comics, written by Scott McCloud (1993). In his book, McCloud uses contributions from semiotics, narratology, history, etc., to "understand" the true nature of comics.

These almost academic books from practitioners of the ninth art gave some support to the work that was being conducted in universities by then. Until that moment, comics had been considered a form of entertainment mostly studied as a kitsch cultural product or only on its graphic aspects. Now, scholars have begun to work seriously on comics as a narrative language on its own.

All this happened especially in Europe, where a "neo-rhetoric" point of view began to focus on the analysis of comics as a narrative system based in the sequence of panels (vid. Eisner) in formats like the strip, the page (or double page) and, at a higher level, the comic-book, the Franco-Belgian album and the recent - from the eighties on"graphic novel".

\section{Nature of comics}

We can relate these forms with the well-known cadre established by Hjemlslev, which sets out the differences between substance and form, and between content and expression. Regarding comics, we are talking about a differentiated kind of sign (comics) determined by the basic substance of its expression (two-dimensional drawings on paper) but also by some sub-forms of expression: strip or page; comic-book, album, or graphic novel. We must not forget that comics not only use drawings but also written 
language - with its graphic aspects too- and peculiar signs like the kinetic lines or the graphic metaphors. From this perspective, we can consider comics as a system of systems, or as a form of expression made of several forms of expression.

\section{Groensteen's "system"}

The principle behind this system of comics is called "iconic solidarity" by the Belgian scholar Thierry Groensteen; a principle that makes comics a medium well differentiated from novels or films. Groensteen defines iconic solidarity "as interdependent images that, participating in a series, present the double characteristic of being separated -this specification dismisses unique enclosed images within a profusion of patterns or anecdotes - and which are plastically and semantically over-determined by the fact of their coexistence in praesentia" $(1999$, p. 18)

According to himself, Groensteen forms part of the neo-semiotic trend in the studies of comics foresaw by Pierre Fresnault-Deruelle as the "fifth stratum" in the history of academic criticism of the ninth art, "where the accent will be placed on the poietic dimension of comics" (1990, p. 587). ' Iconic solidarity is the principle that gives coherence and cohesion to comics and allows the mentioned "poietic dimension," clue of the generation of meaning. Groensteen sees his approach as neo-semiotic in the sense of comics as a complex and meaningful system of significations.

The "neo" part refers to Groensteen considering the search for signifying units "useless", especially minimal and pertinent units like those of languages — phonemes, morphemes, and lexemes, above all (1999, pp. 3-7). The "dictatorship of language", the insistence in applying linguistic categories to other forms of communication, has been frequently disputed in semiotic studies and Groensteen seems to liberate comics from it. This separates his system from important works such as Luis Gasca and Román Gubern's El discurso del comic (1994). In this book, the authors make a detailed review of symbols, visual metaphors, forms of balloons and lettering, stereotypes, and so forth as units of meaning. The book is quite interesting and useful but, as Groensteen repeats frequently, items like the form of balloons are not significant by themselves outside the context of the panel and the codified system of comics.

1 We must be very careful because in the English translation of Groensteen's System of Comics instead of "poietic" we have "poetic", probably a typographical error, but the meaning is quite different (Groensteen, 1999, p. 2). 


\section{Arthrology: Gridding and page layout}

This system is built on the principle of iconic solidarity and develops itself in the physical space where comics will take form and be published. This is what Groensteen calls the "spatio-topia", "a term created by gathering, while maintaining distinct, the concept of space (espace) and that of place (lieu)" (1999, pp. 21-23). The relations among images within this "spatio-topia" compose the "arthrology" - "from the Greek arthron: articulation" (pp. 21) — of the whole work. This "arthrology" can be "restricted" if the relations between panels are within the syntagmatic axis of the narrative sequence —in praesentia - or "general" if the relations are between distant panels - in absentiaand of any other kind but narrative: graphic, semantic, or iconic.

These two different forms of "arthrology" are accomplished through two distinct operations. Restricted arthrology refers to "breaking down" (découpage), the division of the narrative material in pages, strips and, above all, panels. General arthrology comprises the "braiding" (tressage) through which the reader can find relations between distant panels - for instance in color or forms - even in different pages.

Nonetheless, there is a previous operation "at a very precocious stage of creation" called "gridding" (quadrillage). It "consists of dividing the available space into a number of units or compartments" (Groensteen, 1999, p. 144). In other words, the author, before dividing the narrative material in panels and pages, must decide the number of pages (this is, most of the time, an editorial decision) and how he will use those pages. For instance, the disposition of the classical albums of Tintin - from The Blue Lotus onward - is very well known: sixty-two pages with four strips each. Within this space, Hergé had to develop his story. Another example: Burne Hogarth used a very clear grid in his Tarzan but was gradually increasing the dimensions of the panels and, therefore, using less panels per page: from the $4 \times 3$ grid inherited from Hal Foster (four strips, three panels per strip), to the $3 \times 2$ page, most of the time using long panels, and only three or four per page. Recently, the best example of gridding imposing itself over other considerations is maybe the strict $3 \times 3$ grid that Dave Gibbons used in Watchmen.

This gridding creates the page as a "hyperframe", the extradiegetic space where the frames of the panels - explicit or not- are integrated. As Groensteen points out, the hyperframe must not be confused with the notion of "multiframe"; the latter being an 
ensemble of frames (panels) according to their narrative content and connected with breakdown and braiding rather than gridding. The notion of hyperframe refers only to the initial design of empty pages.

The notions of the hyperframe and the multiframe must not be confused. The notion of the hyperframe applies itself to a single unit, which is that of the page. The forms of the multiframe, on the other hand, are multiple. The strip, the page, the double page, and the book are multistage multiframes, systems of panel proliferation that are increasingly inclusive. [...] Piling up the printed pages on the recto and the verso, the book itself constitutes a paged multiframe. (Groensteen, 1999, p. 30)

Over the empty hyperframe or matrix of the page, the author performs the actual "page layout" (mise en page). The panels, together with their narrative content, will acquire their fundamental characteristics with the page layout: form, area (proportions) and site (ubication within the page or double page) (Groensteen, 1999, p. 34).

The location of the panel in the page is a matter of significant importance because "[t]he site of a panel determines its place in the reading protocol" (Groensteen, 1999, p. 34). We must not forget that reading comics is quite different from reading literature. In comics, when the reader opens the page, he can see the panels of the whole (double) page and recognizes some patterns: disposition of the page and panels, size and form of the latter, etc., as well as colors and forms. The fact is that we are always seeing contiguous panels with our peripheric vision, which imposes a prevalence to the iconic and graphic aspects of the page or double page as a whole.

Hergé can give us several examples about the importance of the panel's location in the page. For instance, in page 28 of Tintin in Tibet, the panel with the image of the crashed plane is right in the middle of the page, occupying two complete strips of the usual four strips grid used by Hergé; in other words, it uses the space of six or eight "normal" dimensioned panels. We must not forget that it is an even page, so the attention of the reader is immediately attracted by this panel a soon as he turns the page, passing over the other three of the upper strips, which are, as a matter of fact, only a transition from the previous page. We can see another example in the nine panels grid of the above-mentioned Watchmen, with its mirror effects, especially in double pages. 


\section{a. Arthrology: Breakdown and braiding}

Gridding and page layout combine with two other operations which give its specific traits to the arthrology of comics: "breakdown" (Fr. découpage) and, as Groensteen calls it, "braiding" (Fr. tressage). Until now, we have spoken about handling the empty form, the substance of expression as Hjelmslev would have said. From now on we will speak about operations made on the narrative content, creating the form of that content -again Hjelmslev. Both will generate the final form of the expression of comics.

\section{i. Breakdown}

About breakdown, Groensteen says:

The positional coordinates of the panel do not stem merely from the parceling of the space; they are also determined by a partition of time. The position of a panel in the page corresponds to a particular moment in the unfolding of the story, and also in the process of reading. If the page layout defines the spatio-topical parameters of the panel (its form, its area, and its site), it is the breakdown - the agent of restrained arthrology — that confers its temporal coordinates. (1999, p. 35)

This partition "seizes pre-existing narrative material (drawn up or not, somewhat vague or already structured), and it transforms this fable ${ }^{2}$ or this discourse into a succession of discrete units, the panels, which are frequently associated with verbal utterances, and that are links of a narrative chain" (1999, p. 142). Breakdown is directly related to the mise en scène and is the division of a continuous story in parts - the panels - which conform the basic pieces of narrative sequences (Groensteen, 1999, pp. 117-121).

Breakdown is not only carried on narrative content, but also on other important aspects, such as on the perspective from which this content is to be seen, or on the kind of plan that will be used (both terms in their cinematic sense), and that is the reason of its intimate relation to the mise en scène. In breakdown, if the writer and illustrator are not the same person, the role of the scriptwriter is crucial, although for Groensteen breakdown especially underlines the aspect of the illustrator also as narrator.

2 In the Aristotelian sense. Gérard Genette would have called it "story" (histoire). 
About this matter, it is very interesting to see the various styles of relationships between scriptwriter and illustrator, as David Muñoz does in his book Escribir con viñetas, pensar en bocadillos (Writing with Panels, Thinking in Balloons) regarding the "Marvel method". Here, the role of the writer can range from simply outlining the events - usually following the guidelines of the editor of the series, as it is the illustrator who contributes more to the work - to providing incredibly detailed scripts, as Alan Moore used to write. According to Muñoz, in this last case "the illustrator will pass more time reading the script than drawing it" (2020, pp. 137-162).

The basic difference between gridding/quadrillage and breakdown/découpage resides in the fact that the former operation affects the empty surface of the page, while breakdown works on how to deploy the narrative content on the very same page. However, we must keep in mind that most of the time both operations are simultaneous, and gridding is usually done mentally while performing the breakdown. In fact, Groensteen says that breakdown and page layout (this last one more related to gridding) are "according to a dialectic process [...] mutually determined" (1999, p. 92). In the above-mentioned example of Tintin in Tibet, the decision of creating a big panel in the center of the page with the image of the crashed plane might be considered connected with gridding and page layout. The fact that we see a descriptive image of the plane in the snow at the forefront of the panel and, in the background, against the mountains, the small figures of the adventurers, would be due to breakdown. Another possibility is to see breakdown as the operation that decides how and where the limits between narrative sequences should be drawn, and to leave the task of arranging them in the best way possible in the grid to page layout. In this case, breakdown will be previous or simultaneous to page layout.

\section{ii. Braiding}

Contrary to breakdown, but complementary to it, is braiding (tressage). Braiding is the relation, other than narrative, that panels maintain among themselves, in the page and in the publication itself - comic-book, album, graphic novel or even seriesoffering the reader a unified whole. While "restricted/restrained arthrology"3 are "the linear semantic relations that govern the breakdown" $(1999$, p. 103) and "put in place

3 Both forms ("restricted" and "restrained" can be found in the English translation by Bart Beaty and Nick Nguyen. In the book we can also find that breakdown governs restricted arthrology (p. 22) or, vice-versa, that restricted arthrology governs breakdown (p. 103). As a matter of fact, it does not matter at all. 
the sequential syntagms, which are most often subordinated to the narrative ends" (1999, p. 22), "general arthrology" is the realm of braiding, relations "translinear or distant" that have as an "essential component" the multiframe (1999, p. 22) because "[g]eneral arthrology demonstrates that the panel can also be the object of distant semantic determinations, which overtake the frame of the sequence and proceed to a networked operation" (1999, p. 111).

Groensteen defines braiding as follows: "It consists of an additional and remarkable structuration that, taking account of the breakdown and the page layout, defines a series within a sequential framework" (1999, p. 146).

To be clear, he also defines the concepts of series and sequence as he uses them:

A series is a succession of continuous or discontinuous images linked by a system of iconic, plastic or semantic correspondences. [...] A sequence is a succession of images where the syntagmic linking is determined by a narrative project. (1999, p. 146)

If we go back to the terms used by Roland Barthes in his Introduction à l'analyse structurale des récits, breakdown will deal with cardinal functions (or nuclei) and catalysis; while braiding will stablish their relations through indices and, sometimes, through informants. For instance, the scenes of the death of The Comedian in Watchmen have an intense red background; that way, even if the panels are not consecutive, the reader identifies them as related thanks to the use of color.

Another interesting point about braiding, according to Groensteen, is its double nature as an operation that identifies similarities (a) at the time we turn the page -as happens with the red color in Watchmen - and (b) afterwards, when we remember that specific page or panels while reading others.

Contrary to breakdown and page layout, braiding deploys itself simultaneously in two dimensions, requiring them to collaborate with each other: synchronically, that of the co-presence of panels on the surface of the same page; and diachronically, that of the reading, which recognizes in each new term of a series a recollection or an echo of an anterior term. (1999, p. 147) 
This double-sided relation transforms the site of a panel —located during page layout and given by breakdown - in a place (Fr. lieu) when, over the narrative sequence, the author adds the iconic, plastic and/or semantic elements that configure a series.

This process allows a particular kind of reading: horizontal, vertical or diagonal; in praesentia and in absentia; syntagmatic or associative; narrative or rhetoric. In sum, this offers a reading experience at the same time linear (narrative) or tabular (through braiding) across multiple isotopies in the plane of content and expression, as proposed by Groupe $\mu$ (Rhétorique de la poésie. Lecture linéaire, lecture tabulaire, 1977).

As a matter of fact, braiding allows the possibility of creating the poli-isotopies that Greimas considered typical of the literary text (1966, pp. 147-1554), or, in Jakobson terms, characteristic of the poetic function. In that sense, braiding phenomena have been considered close to stanzas in poetry (Brown, 2017), something that allows Groensteen to speak about effects of "rhyme" in Hergé's The Red Sea Sharks (Coke en stock) (1999, pp. 149-151) following the analysis of Jan Baetens in chapter six of his book Hergé écrivain (1989).

As we have seen, breakdown, page layout and braiding create a complex network of relations among panels. These relations can be extremely complex and make possible an enrichment of the experience of reading comics, but they can be very delicate in case of imbalance among them too. As we are going to see in the following example, a change on gridding might alter this careful balance.

\section{The Seven Crystal Balls: problems with gridding}

We can see a good example of all these relationships and balances in Herge's The Seven Crystal Balls (Les 7 boules de cristal) ${ }^{5}$, the first part of a double adventure together with Prisoners of the Sun (Le Temple du soleil). The publication was a very complicated

4 Cited by the Spanish translation of A. de la Fuente.

5 The panels and pages of Herge's The Seven Crystal Balls used here as examples are cited according to fair use and to the Turkish Law of Intellectual Property (Fikir ve Sanat Eserleri Kanunu) no 5846, article 35, paragraphs 1 and 3:

Madde 35 - Bir eserden aşağıdaki hallerde iktibas yapılması caizdir:

1. Alenileşmiş bir eserin bazı cümle ve fıkralarının müstakil bir ilim ve edebiyat eserine alınması;

[...]

3. Alenileşmiş güzel sanat eserlerinin ve yayımlanmış diğer eserlerin, maksadın haklı göstereceği bir nispet dahilinde ve münderacatını aydınlatmak maksadiyle bir ilim eserine konulması 
process, and as Fernando Castillo says: "The publication of the two albums of the reporter [Tintin] dedicated to his Peruvian adventure is characterized by being one of the most eventful of the couple formed by Tintin and Hergé" (2011, p. 185).

With the German occupation of Belgium in 1940, the newspaper Le Vingtième Siècle was closed and Hergé had to leave the weekly supplement Le Petit Vingtième. Soon afterwards he began publishing the adventures of Tintin in another newspaper, Le Soir - at the time, controlled by the Germans occupiers-, at first in the weekly supplement for children and teenagers, and after September 1941 in daily strips in the newspaper itself. This meant a first change in format, strips being very different from pages from the gridding point of view, and therefore of breakdown too. To begin with, daily strips are longer than the strips of the album: three daily strips roughly equal the four strips of a page. And a daily strip needs a certain cliffhanger at the end too, a panel that must fit in the network of the album page.

\section{a. Hergé's working method and the interruption of The Seven Crystal Balls}

However, by drawing pages or daily strips, Hergé worked thinking in terms of the final album, especially when he began publishing Tintin's adventures with Casterman in 1934. Technical needs of color printing after 1943 imposed a format of sixty-two pages: four sixteen-pages booklets, inner title page and legal credits page included (Sadoul, 1983, p. 39), and Hergé had to adapt to it.

We know, thanks to Hergé himself, how the process of creation of his albums in the late sixties and seventies was, from Flight 714 (Vol 714 pour Sydney, 1968) to Tintin and the Picaros (Tintin et les Picaros, 1976), so we can assume that it would not have been very different in the forties. First of all, he wrote a brief synopsis of the argument of about two or three pages ("not more"), and then he proceeded to breakdown/découpage"per page", which was"the most difficult part of the job [...]. A job of a watchmaker or a Benedictine monk. Or a Benedictine watchmaker". In every page he included some suspense at the end, as well as notes, outlines and sketches for the characters, the essential ideas for the dialogue, indications for the background, and so forth. Once this breakdown was finished, almost as a storyboard but with more extra material, he proceeded to do "the work itself in great format sheets". That was the time of real drawing. After that, he made a neat copy in another sheet that would be the definitive page over which his collaborators would work to add texts, backgrounds, color, and so on. (Sadoul, 1983, pp. 39-45). 
Luckily, great quantities of material about Hergé's working system are available today. In the same book of interviews by Numa Sadoul we can find the reproduction of part of the initial synopsis of Flight 714, drafts, studies on characters, one page of the breakdown of Flight 714 and another page fully drawn, but before the neat copy, of The Red Sea Sharks. Another very well documented book which explains the creation of Flight 714 in detail is How a Comic Is Born: Spying Hergé (1993) by Phillipe Goddin. Finally, the publication of the unfinished album Tintin and Alph Art allow us to see directly the process followed by the author. And there is much more.

The first problem Hergé faced in 1944 was the conversion of the daily strips in album pages. To achieve it, from April 1944 onwards, Hergé cut the panels of the strips and glued them in a notebook like doing a puzzle. This implied eliminating, adding or changing panels, as can be seen in the commented edition published by Philippe Goddin (2014b, pp. 82-83).

On September 3,1944, Brussels was liberated by British troops, which meant that Le Soir ceased to be published immediately for having been the newspaper of the German occupiers. Therefore, this also interrupted the adventures of Tintin, whose last strip, $\mathrm{H}-153$, was published on the day of the liberation, Sunday. Hergé is seen with suspicion and frequently accused of collaborationism. Nevertheless, he avoids jail with the support of members of the Belgian resistance and survives doing some jobs for Casterman (Castillo, 2011, pp. 190-197). Even if the albums of previous adventures were normally published by Casterman, Tintin will not meet again with his readers until the last days of September 1946, a gap of two years.

The Seven Crystal Balls began to be published in Le Soir in December 1943 and would not appear as an album until 1948, although Hergé initiated the preparations in September 1944 (Goddin, 2014, p. 116) and announced to Casterman it would be ready for 1946. The album had to be delayed because, in the meantime, Hergé received a proposal from Raymond Leblanc, a publisher that took part in the Resistance: to create a weekly magazine and to be its artistic director. The magazine will be called Tintin, and the journalist would be its principal attraction. Hergé would finish the adventure of the seven crystal balls in this magazine. But, where and how to continue it after a hiatus of two years? 


\section{b. The publication in Tintin magazine}

The rest of the adventure began to be published in Tintin magazine in September 1946 with the title of its second part, Prisoners of the Sun (Le Temple du soleil), meaning that Hergé did not have the intention of presenting it as a continuation of the material published at Le Soir. The idea was to use the twelve pages of the rest of the album The Seven Crystal Balls as a prologue for the adventure in Peru. We know that Hergé went on preparing the pages for the album after the closing of Le Soir and that, at the end, the twelve pages needed for finishing the book would later become fifteen because some scenes would be deleted or suffer a change of place -as happened with the reencounter of Tintin with general Alcázar- (Goddin, 2014, p. 124). Hergé would also include in the album some big panoramic half-page panels, as the scene in the theater or the one in the hospital (Goddin, 2014, p. 122).

However, Hergé faced two important problems. The first of them was the load or work for him: apart from drawing Tintin he had obligations as artistic director of the magazine and some other duties as the person responsible for the character - answering the letters of the readers directed to Tintin, for instance--, as well as his commitments with Casterman. Tintin would occupy the two central pages of the magazine, and two pages per week was too much for Hergé. The solution would be to publish the pages in a format a l'italienne - "Italian style" -, meaning that the panels would occupy the whole width of the double page horizontally: three strips instead of four and more panels per strip. Hergé would design the new pages of Prisoners of the Sun directly in that format and would adapt those already prepared for the album of The Seven Crystal Balls. However, as we will see, this decision would force a new gridding, leading to some consequences in the arthrology of the page, affecting braiding.

The second problem was how Hergé could give the new readers enough information of what had happened until that moment. To solve this dilemma, Hergé included a scene parallel to the one that initiated the adventure. The six first strips as published by Le Soir in December 1943 are as follows: Tintin is on a train reading a newspaper article about the story of the expedition to Peru that found the mummy of Rascar Capac. A gentleman next to him with a moustache, glasses and a bowler hat, reading the paper over his shoulder, makes some remarks about the news. The train arrives to the village of Marlinspike (Moulinsart). Tintin and Snowy (Milou) go to the castle taking a stroll. Snowy runs and plays with a butterfly and fall in a water puddle or a stream. 
They arrive to the castle, knock on the door, and Nestor, the butler, opens it. In the album edition, Hergé deletes the sequence of Snowy playing with the butterfly, which will cause a slight problem of coherence that has been repeatedly noticed by Tintin fans: in the first panel on the second page of the album, Snowy appears running very happy, but in the next panel he seems angry for no visible reason.

In September 1946 Le Temple du soleil opened in the weekly Tintin magazine with an absolutely parallel scene. We must not forget that this is not really Prisoners of the Sun - that would begin with the arrival of Tintin and Haddock to Peru-, but an introduction to the remaining pages of The Seven Crystal Balls, targeting those readers who did not follow the adventure from the beginning. Repeating the scene with slight differences and with a very similar breakdown, Hergé was playing a joke that would only be understood by those readers who read Le Soir. This time Tintin is on a bus instead of on a train, and the newspaper he is reading does not speak about the expedition to Peru, but instead gives a summary of what was published in Le Soir. Just behind Tintin there is a gentleman with a moustache, glasses and a hat, who suspiciously resembles the one from Le Soir. On their way to Marlinspike castle, Snowy plays this time with a hedgehog instead of a butterfly, but with bad consequences as well. However, the one who falls into the water now is Tintin, who was distracted reading the paper. This is connected to three of the four last strips of August-September 1944 ( $\mathrm{H}-150$ to $\mathrm{H}-152)$, especially the first one in which Tintin collides with general Alcázar because he is distracted reading a paper. The whole scene of the stroll to the castle will be deleted for the album because otherwise it would be excessively redundant, while the encounter with Alcázar will change its place to page 57 (and from Brussels to SaintNazaire/Westermouth).

However, some parts of this introductory scene are maintained in the album. Specifically, the second strip of page two is repeated in the first two strips of page fifty. Tintin and Snowy arrive at the castle, he knocks on the door and Nestor opens it and both speak. The scene is practically the same, except for the position of Snowy - first at one side of Tintin and then at the other- and other minor details.

There is also some lack of harmony in the distribution of panels in page 50. While in page two these three panels form a strip only, in page fifty they are between two strips because Hergé included three panels to connect this sequence to the hospital scene, added exclusively for the album and that was not published in Le Soir. (Figures 1 and 2). 

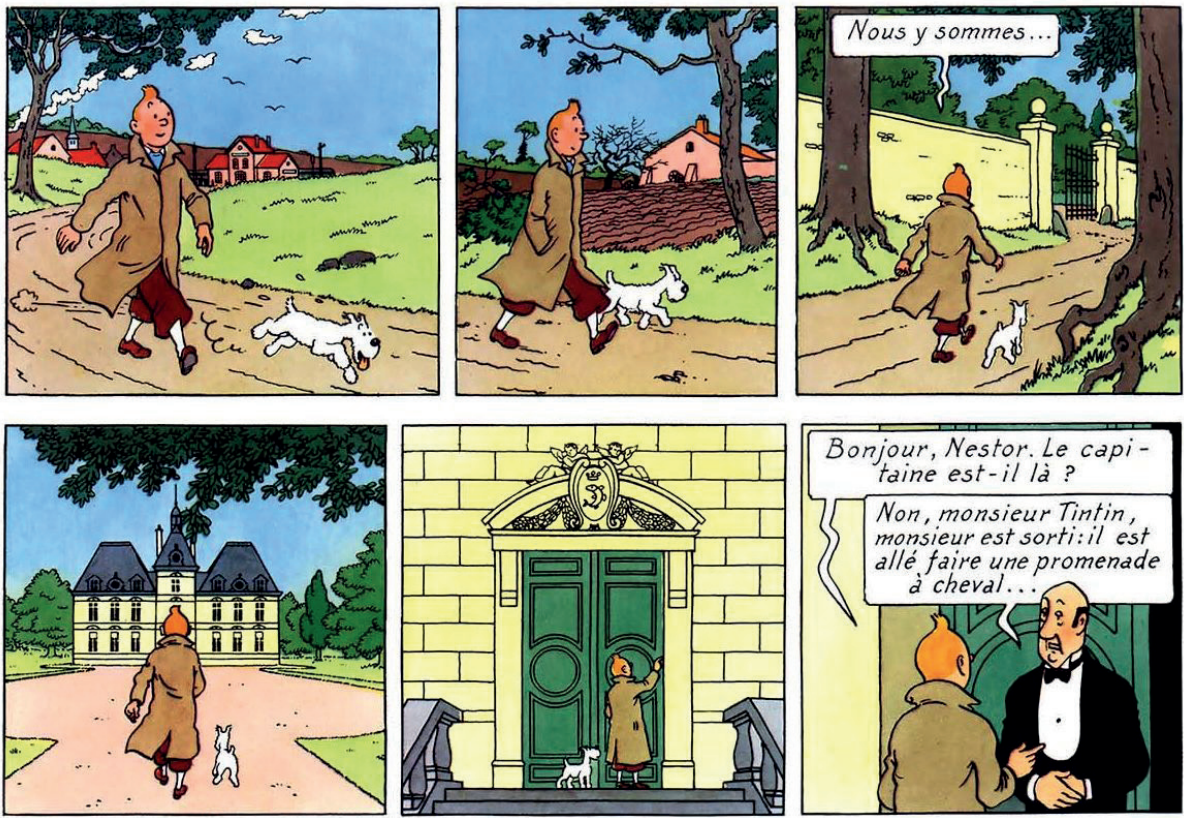

Figure 1. Hergé: Les 7 boules de cristal. Tournai : Casterman, 1955, p. 2
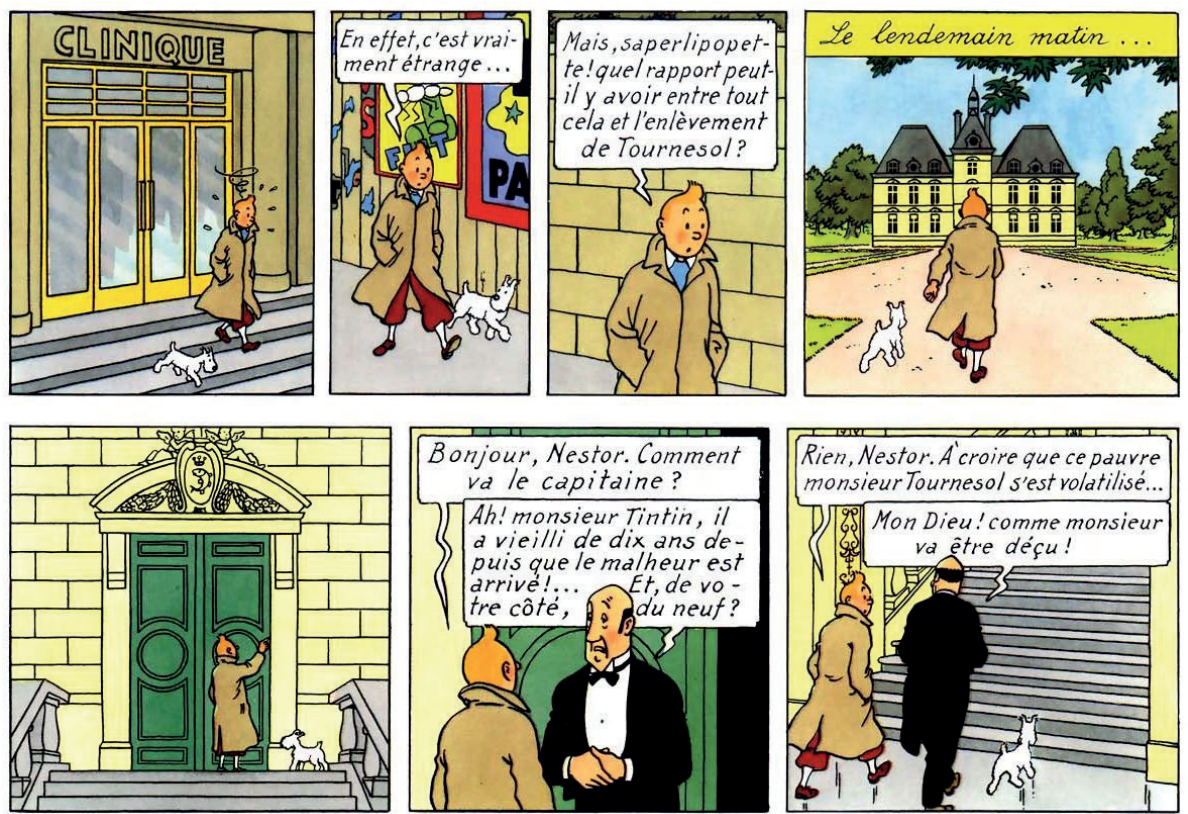

Figure 2. Hergé: Les 7 boules de cristal. Tournai : Casterman, 1955, p. 50 
As we said before, it seems like the first scenes published in the new magazine in 1946 - the bus, the stroll to Marlinspike castle, the accidents of Snowy and Tintin — were some kind of a joke directed to readers who already knew the story. More difficult to understand is the repetition of the three panels of the arrival at the castle in the same album. However, from the point of view of braiding, they offer an echo effect that has a very interesting narrative function. We must keep in mind that the second scene never appeared in the strips prepared for Le Soir, even those that were unpublished (Goddin, 2014, pp. 114-115). So, why did Hergé consider it necessary to repeat them in the final album? In our opinion, because they mark an important turning point in the story.

When Tintin arrives at Marlinspike castle for the first time in page two, he finds that captain Haddock has become some kind of country aristocrat who spends his time riding horses (with very bad results), wears tweed jackets and uses monocles that he does not need and continuously loses. It is a very shocking transformation from the merchant sailor of the previous episode — Red Rackham's Treasure-, in which he bought the castle.

In his second arrival - page 50-, Tintin finds a very depressed captain Haddock, sunk in an armchair and wearing his pajamas. However, in the last panel of page 51 - the page on the right - he suddenly appears again as the sailor he used to be. It is an explosive effect thanks to a wise (double) page layout and the care in programming the last panel of the page that Hergé usually took:

Once the script is ready, I proceed to the breakout, to the breakout by page. And that is the most difficult job because it needs some suspense or some outcome at the end of every page. (Sadoul, 1983, p. 39)

It seems that the panel of the spectacular transformation of Haddock was programmed to be published in Le Soir two weeks after its closing and was even already drawn. Although this panel is lost, it is clear that the reappearance of Haddock as sailor was thought from the beginning (Goddin, 2014, pp. 114-115).

In other words, we can establish that every arrival of Tintin to the castle in the album is a prelude for a metamorphose of captain Haddock, unexpected for the reader. From sailor to country gentleman, from gentleman to brave sailor again. There is the possibility that this was precisely the motive to repeat almost identically those three panels, to 
give the reader a clue that a transformation was on its way. "Almost" identical, because Hergé includes some light differences to demonstrate that it is not a mistake but a very carefully thought decision.

About repetitions and their differences -in this case, Snowy to Tintin's right or left side-, Groensteen says:

Let us note that no panel can be integrally repeated without modification. The reprise of the same panel at two locations in a comic, contiguous or distant, does not constitute a perfect duplication. The second occurrence of the panel is already different from the first by the sole fact of the citation effect that is attached. The repetition raises the memory of the first occurrence, if it is a matter of a rhyme (distant repetition), or manifests a singular insistence, if the two occurrences are contiguous. But most important is that being isomorphs, these panels cannot be "isotopes"; by definition, they cannot occupy the same site. (1999, pp. 148-149)

The braiding that takes place between pages two and fifty does not go unnoticed to the attentive reader. It is a clear manifestation of Groensteen's "general (or distant) arthrology", the relationship that a panel establishes with others from the same book, but not always in the same page.

The other relations, translinear or distant, emerge from general arthrology and decline all of the modalities of braiding (tressage). They represent a more elaborated level of integration between the narrative flux [...] and the spatiotopical operation, in which the essential component, as Henri Van Lier has named it, is the "multiframe" (multicadre). (Groensteen, 1999, p. 22)

At this point, it is convenient to remember the difference established by Groensteen between sequence and series. A sequence is a purely narrative element, as described by Bremond in "The Logic of Narrative Possibilities" ("La Logique des possibles narratifs", 1966, especially pp. 60-63); therefore, it enters directly in the terrain of breakdown, which segments the narrative content in panels and gives them a site in the page through the page layout. Series are any association of panels through "iconic, plastic or semantics correspondences" (Groensteen, 1999, p. 146); in other words, correspondences that can be established between panels for any motive, apart from their narrative content. 


\section{c. Modification of braiding by changes in gridding}

Sequences are linear and follow the Western world's reading order, from left to right and from top to bottom - Japanese mangas function differently. Series can be established following other parameters and between non-contiguous panels. Roberto Bartual simplifies this distinction even more, precising that (a) non-narrative sequences can exist - descriptive, argumentative, poetic-symbolic -, and that (b) the fundamental distinction between sequences and series is that, in the first ones, the order of images is necessary to constitute a discourse, whereas in series "the order of images does not articulate dependence relations" and they do not obey the intention of creating a discourse, but, according to Natalie Barberger "to an intent of enjoying the pleasures of combinatory excesses" (Bartual Moreno, 2010, pp. 115-119).

For instance, we have seen the effect of "rhyme" when there is a relation of braiding among the panels at the right of the page along its vertical axis. We are going to use these structure -among others - in a page of The Seven Crystal Balls to illustrate of how changes in gridding can deeply affect the relations of braiding, even if the narrative content —-the sequences, in sum — remains intact.

As we have said, Hergé was preparing the album The Seven Crystal Balls when, in 1946 , he began publishing again what remained of the adventure in the new format of double page a l'italienne. He had the pages ready for the album - with the page layout in a gridding of three-four panels per four strips per page-, so he just had to pass the panels to another format of three strips of five or six panels each, adjusting the dimensions of the panels and adding or deleting when necessary. But this caused some problems on braiding.

Page 60 of the album gives us a good example of carefully planned braiding relations. The page seems to be divided into two halves. The upper half is dominated by the yellow background of the wooden boxes -except in the first panel, where there are brown sacks, even though the difference is insignificant-, and the "camera" is always looking from the sea to the docks. In the lower part, the background is the blue of the sky and the water, and the grey of the pavement and the stairway. Additionally, the third and fourth strips form a sequence: in the third, Tintin throws the hat into the water; in the fourth, he retrieves it. The third strip is reinforced by an effect of braiding: both Tintin and Haddock have been drawn looking back in the three panels. In most of the fourth strip we have the decomposition of a single motion: Tintin takes the hat 
and sees something in it. And we could find even more items of cohesion at the levels of page, half page and strip.

However, from the point of view of braiding, one of the most noticeable effects is the "rhyme" established between the last panels of every half page. In the right panels of the upper half, Tintin has approximately the same stance: he is holding the hat with his fingertips with Snowy next to him. In the lower half, the rhyme is achieved by means of the big exclamation marks in their vertical balloons - the first marks are straight, the last one slightly undulated - . In this last panel, Tintin is again with the hat in his hands, like in the first two strips.
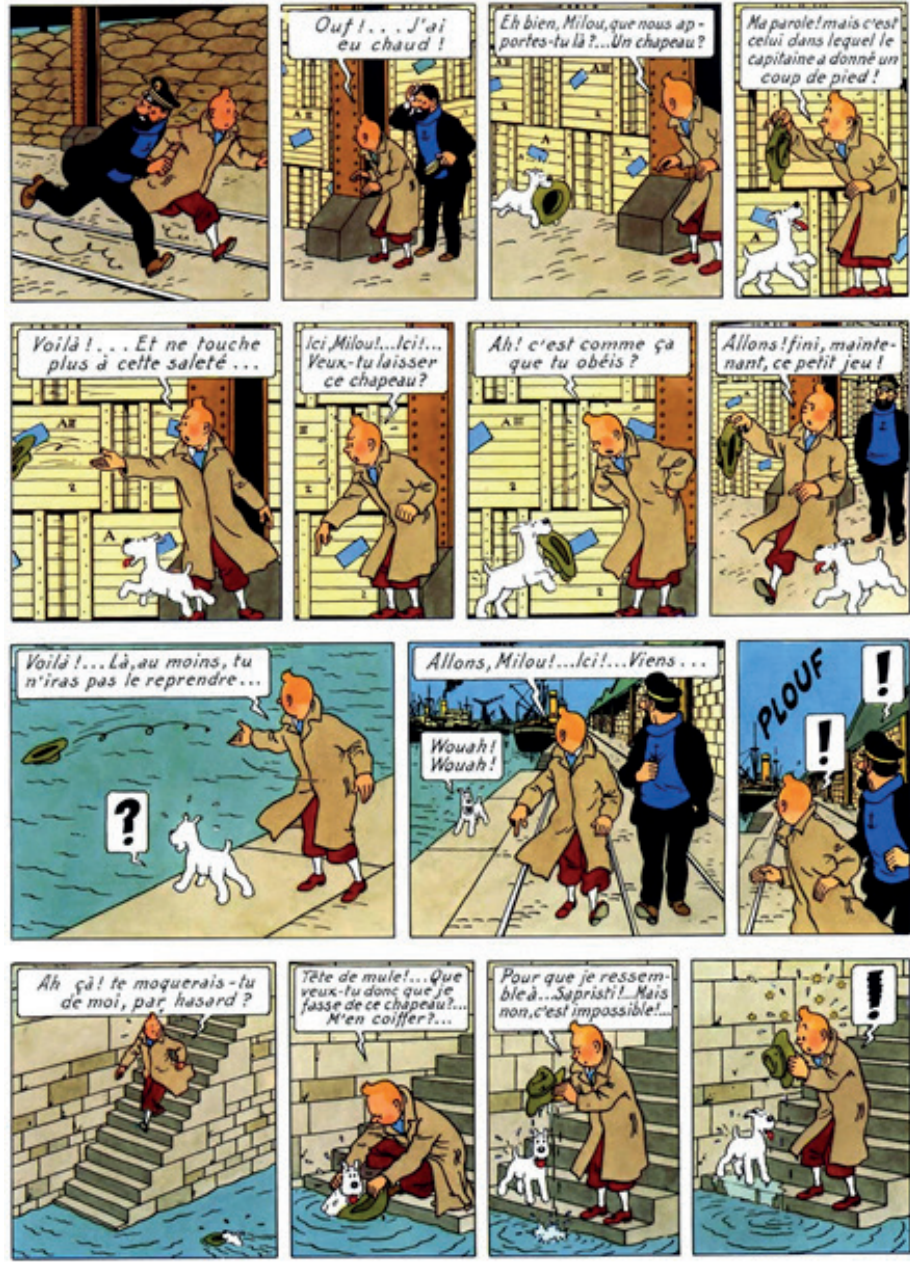

Figure 3. Hergé: Les 7 boules de cristal. Tournai : Casterman, 1955, p. 60 
All these effects disappear in the double page à l'italienne which was published initially in Tintin magazine on December 5, 1946. A different gridding means a displacement of the panels, which altered all these carefully made background and rhyme effects that gave more unity and cohesion to every strip and half pages.

The page published in the magazine adds a panel for "geometric" balance and as a transition with the page of the following week (on December 12). This panel does not appear in the album —we must remember again that the pages for the album were prepared before their publication in the magazine- because it is a repetition of the first panel of page 61 with some different details only, the most important of them being the presence of captain Haddock. It is obvious that the added panel is redundant and has no sense in the album even if it helps to maintain cohesion between one week and the following in the magazine. Furthermore, being respectively even and odd pages in the album, they appear at the same time at the reader's view as soon as one opens the book, and one does not need to turn the page to follow to the next sequence.
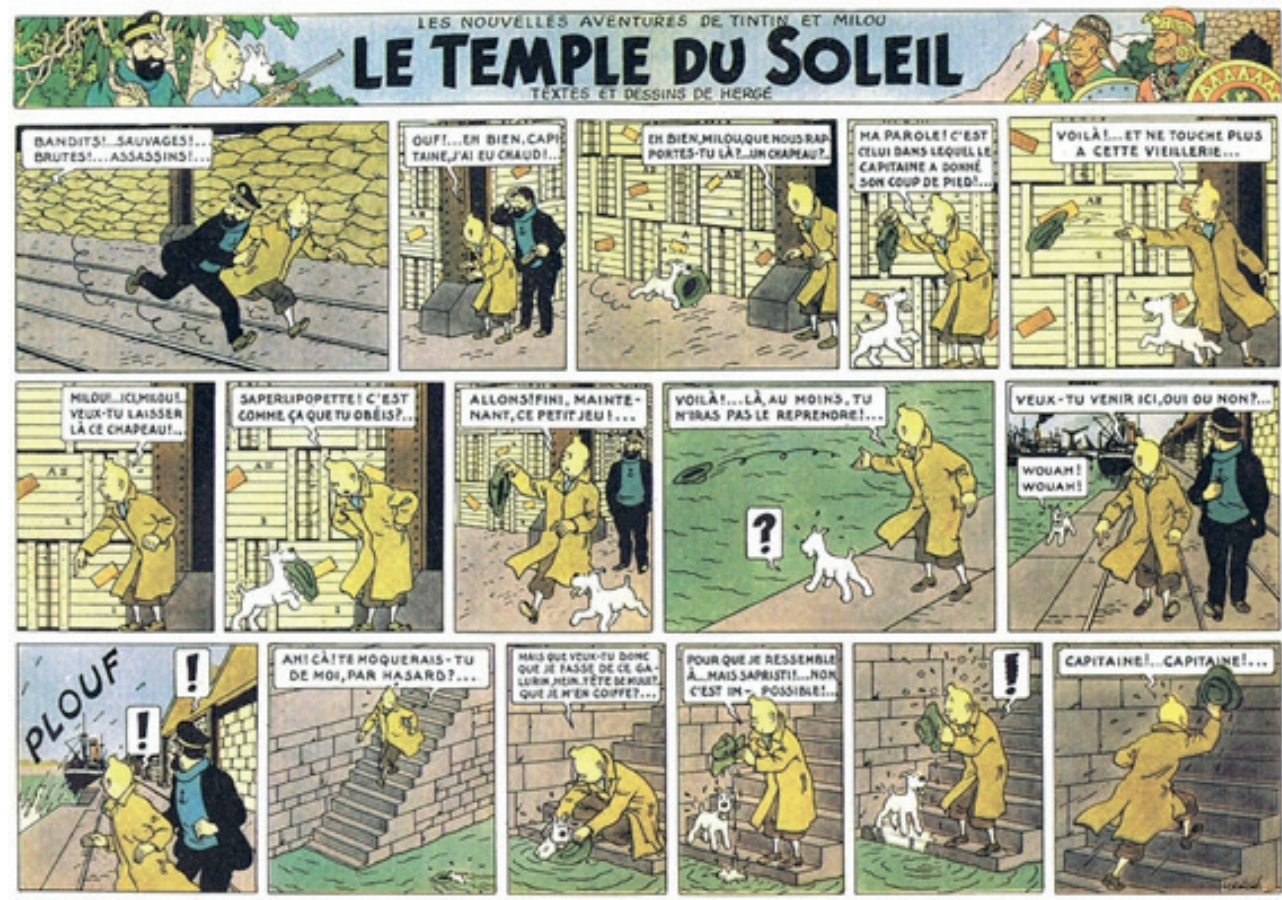

Figure 4. Hergé: La Malédiction de Rascar Capac. 2 Les Secrets du Temple du soleil. (Ed. by Philippe Goddin) Bruxelles: Moulinsart/Casterman, 2014, p. 35 


\section{Conclusion}

In his Ph.D. dissertation, Daniel Gómez Salamanca presents a collection of definitions of comics, underlining that they are usually formulated following three parameters: comics (a) as a means of communication that interrelates images and text, this one being the base for the more classical definitions; (b) as a sequential art, after the seminal book of Will Eisner; (c) as a mass-medium and/or a language; and (d) as a social object that defies to be defined (Gómez Salamanca, 2013, pp. 49-65). In this classification, we might miss the contribution of Groensteen's book: the conception of comics as a system. We can align this idea with the classical thinking of structuralism, even if Groensteen sees himself more part of the neo-semiotic trend.

As we have said, he departs from the notion of "iconic solidarity" among series of images as a basis for his view of comics as a system. The series formed by this iconic solidarity might be narrative sequences, following the habitual reading order, or series strictly speaking, if there are other kind of relations. The essential operations that relate the images - the panels - among them are, on the one hand, the breakdown (découpage), directly connected with the page layout (mise en page) and dividing and organizing the narrative content; on the other, the braiding (tressage), which forms series according to non-narrative principles. These three operations are interrelated to a certain extent too. The page layout depends absolutely and essentially upon breakdown, but also some aspects of braiding will rest on how panels are distributed on the page, for instance, rhyme and graphic similitudes inside the strip. Besides, all these operations depend upon the initial gridding, which "consists of dividing the available space into a number of units or compartments" (Groensteen, 1999, p. 144). Groensteen specifies the interrelations between gridding and the rest of the operations as follows:

Gridding, therefore, defines the first, and often crudest, configuration of the multiframe. This provisory configuration furnishes the author with a framework, a matrix. The page layout becomes an improved and corrected version of the gridding: that is to say the version informed by the precise contents and by the two other constitutive operations of arthrology, the breakdown and (if the case arises) the braiding. (1999, p. 145)

As we have seen with the example of The Seven Crystal Balls, any change made in this gridding will likely have more or less important effects on the braiding relations. 
Obviously, it also affects the page layout - a vertical page of four strips and a horizontal one of three are not the same-, and this sometimes not only necessitates the adjustment of the dimensions of some panels, but the addition and/or maybe elimination of others to make everything fit correctly in the new format.

Braiding also creates relations in absentia when it connects panels or elements belonging to different pages of the same work, or even different volumes of the same series.

Braiding thus manifests into consciousness the notion that the panels of a comic constitute a network, and even a system. To the syntagmatic logic of the sequence, it imposes another logic, the associative. Through the bias of a telearthrology, images that the breakdown holds at a distance, physically and contextually independent, are suddenly revealed as communicating closely, in debt to one another [...]. (Groensteen, 1999, p. 158)

This network, a consequence of all these relations among the various levels of comics — panel, strip, page (and/or double page), book/magazine—, produces a unique reading experience that distinguishes comics from other narrative modalities, such as epic poetry, novel, cinema, and so forth. In sum, comics can be analyzed not only as a narrative means of communication that combines image and text, and that is linked to mass media, as it has usually been done, but also as a unique system of interdependent elements, much in the sense of traditional saussurean structuralism. Of course, this vision leaves aside the analysis of the graphic/iconic aspects, but this corresponds to a more "classical" semiotics, as demonstrated by Umberto Eco in his book Apocalittici e integrati (1964). In any case, Groensteen's neo-semiotic (or neo-structuralist) approach can be particularly useful in the analysis of narrative components in comics and its peculiar rhetoric effects.

Peer-review: Externally peer-reviewed.

Conflict of Interest: The author has no conflict of interest to declare.

Grant Support: The author declared that this study has received no financial support.

Hakem Değerlendirmesi: Dış bağımsız.

Çıkar Çatışması: Yazar çıkar çatışması bildirmemiştir.

Finansal Destek: Yazar bu çalışma için finansal destek almadığını beyan etmiştir. 


\section{References}

Baetens, J. (1989). Hergé écrivain. Paris: Flammarion (2006, corrected and augmented edition).

Bartual Moreno, R. (2010). Poética de la narración pictográfica: de la tira narrativa al cómic (Ph. D. Thesis). Madrid: Universidad Autónoma de Madrid.

Bremond, C. (1966). "La Logique des possibles narratifs". Communications (Recherches sémiologiques: I'analyse structurale du récit) no 8, pp. 60-76.

Brown, M. (2017, September 6). "On Watchmen and Shakespeare, the 9-Panel Grid and lambic Pentameter". https://comicbook.com/comics/news/on-watchmen-and-shakespeare-the-9-panel-grid-and-iambicpentameter/ Last visited 10/10/2020.

Castillo, F. (2011). Tintín-Hergé. Una vida del siglo XX. Madrid: Fórcola.

Fresnault-Deruelle, P. (1990). "Semiotic Approaches to Figurative Narration". In T. Sebeok (Ed.), The Semiotic Web 1989. Berlin, New York: Mouton de Gruyter, pp. 587-603.

Goddin, P. (2014a). «Recherches et commentaires (1)». In Hergé, La Malédiction de Rascar Capac. 1. Le Mystère des boules de cristal. Bruxelles: Éditions Moulinsart/Casterman.

Goddin, P. (2014b). «Recherches et commentaires (2)». Dans Hergé, La Malédiction de Rascar Capac. 2. Les Secrets du Temple du soleil. Bruxelles: Éditions Moulinsart/Casterman.

Gómez Salamanca, D. (2013). Tebeo, cómic y novela gráfica: La influencia de la novela gráfica en la industria del cómic en España (Ph. D. Thesis). Barcelona: Universitat Ramon Llull.

Greimas, A. J. (1966). Semántica estructural. Investigación metodológica. (A. de la Fuente, Trans.). Madrid: Gredos, 1971.

Groensteen, T. (1999). The System of Comics. (B. Beaty, \& N. Nguyen, Trans.). Jackson: University Press of Mississippi, 2007.

Groupe $\mu$. (1977). Rhétorique de la poésie. Lecture linéaire, lecture tabulaire. Paris: Éditions du Seuil, 1990.

Gubern, R., \& Gasca, L. (1988). El discurso del cómic. Madrid: Cátedra.

Hergé. (2014). La Malédiction de Rascar Capac. 1. Le Mystère des boules de cristal. Bruxelles: Éditions Moulinsart/ Casterman.

Muñoz, D. (2020). Escribir con viñetas, pensar en bocadillos. Manual de guion de cómic. Madrid: Es Pop Ediciones.

Peeters, B. (1988). Hergé en el país de los incas. In Hergé, El templo del sol (versión original) (pp. 7-19) (Trans. by J. Renau). Barcelona: Juventud, 1991.

Peeters, B. (2002). Hergé, fils de Tintin. Paris: Flammarion, 2006.

Sadoul, N. (1983). Entretiens avec Hergé. Tintin et moi. Bruxelles: Casterman. 